\title{
Modernidad, historia y emancipación en la Teoría del cine de Siegfried Kracauer.
}

Modernity, history and emancipation in Siegfried Kracauer's Theory of Film.

DOI: $10.32870 /$ sincronia.axxv.n79.24a21

\author{
Juan Diego González Rúa \\ Centro de Estudios en Ciencias y Humanidades (COLOMBIA) \\ CE: diego.gonzalez@udea.edu.co / ID ORCID: 0000-0001-6304-843X
}

Esta obra está bajo una Licencia Creative Commons Atribución-NoComercial 4.0 Internacional

Recibido: 08/07/2020

Revisado: 03/10/2020

Aprobado: $19 / 11 / 2020$

\section{RESUMEN}

El artículo analiza la Teoría del cine de S. Kracauer, como el planteamiento de una teoría crítica no-sistemática de la modernidad. Antes que una teoría estética del medio cinematográfico, en la obra se construye una crítica frente a las formas históricamente peculiares que asume la experiencia moderna. Kracauer aborda el cine como un medio de caracterización de las paradojas de esta sociedad, que expone tanto sus mecanismos de opresión, como los potenciales emancipatorios que le resultan inmanentes. En definitiva, el abordaje kracaueriano del cine apunta a la posibilidad de reorientar el presente hacia una organización pos-metafísica del mundo social.

Palabras Clave: Teoría crítica. Modernidad. Racionalización. Crisis de la experiencia. Contingencia. 


\section{ABSTRACT}

This paper analyzes S. Kracauer's Theory of Film, in terms of the definition of a non-systematic critical theory of modernity. Far from an aesthetic theory of the cinematographic medium, this approach makes a deep criticism against the historically peculiar forms assumed by the modern experience. Kracauer defines cinema as the expression of a paradoxical society, which exposes both its mechanisms of oppression, and the emancipatory potentials that are immanent to it. In short, Kracauer's approach to cinema points to the possible transformation of the present towards a postmetaphysical organization of the social world.

Keywords: Critical Theory. Modernity. Rationalization. Crisis of Experience. Contingency.

\section{Introducción}

En este artículo analizo la Teoría del cine de S. Kracauer, con el fin de reconstruir algunos elementos que resultan centrales a una teoría crítica no-sistemática de la modernidad ${ }^{1}$. En contravía de posturas que convirtieron el planteamiento kracaueriano en una suerte de ruina filosófica desde la que difícilmente podría derivarse un sentido político (Hansen, 2012, p. 278), mostraré que, en esta obra, Kracauer aborda el cine como vector de comprensión crítica de la sociedad moderna. Se verá que, antes que una perimida teoría estética (Adorno, 2003), la concepción kracaueriana ofrece importantes herramientas de análisis, no solo frente a las formas históricamente peculiares que asume la experiencia moderna, sino a las paradojas consustanciales a esta sociedad. Desde su abordaje del medio cinematográfico, Kracauer expone, tanto las formas de opresión y totalización iluministas, como sus potenciales emancipatorios inmanentes. Desde esta perspectiva, el cine permite un extrañamiento que patentiza el carácter espurio de la segunda naturaleza gestado en la modernidad capitalista, al tiempo que anuncia la posibilidad de su superación. De allí se desprende una concepción de la historia que se opone a toda idea totalizante y acabada frente a esta, exponiendo su carácter contingente y transitorio. En definitiva, se verá que el abordaje

1 Sobre el potencial crítico de la concepción kracaueriana del cine, (Hansen, 2012); (Schlüpmann, 1991); (Perivolaropoulou, 2004); (Agard, 2016); (Von Moltke, 2010); (Harbord, 2007); (Elsaesser, 2014). 
kracaueriano del cine señala la posibilidad de reorientar el presente en términos de una organización pos-metafísica del mundo social, en cuyo seno la diferencialidad se sustraiga al allanamiento impuesto por toda forma abstracta y opresiva de totalización.

\section{Modernidad y crisis de la experiencia}

La obra de S. Kracauer aborda las transformaciones ocasionadas por el avance del proceso modernizador ocurrido durante la primera mitad del siglo XX. En ese mundo, la expansión del capitalismo, la visión científica del mundo y la acelerada masificación urbana habían disuelto paulatinamente los sistemas tradicionales de creencia y sentido que anteriormente garantizaban la cohesión y estabilidad social (Kracauer, 1995, p. 129). La modernidad significaba el paso de una comunidad orgánica (Gemeinschaft) a una sociedad tecnológico-funcional (Gesellschaft), en cuyo seno las formas de socialización se hacían cada vez más abstractas e impersonales (Kracauer, 1995, p. 13). Precisamente, para Kracauer, el rasgo central al proceso de racionalización moderno se define por su creciente tendencia a la abstracción. Así como el proceso de intercambio capitalista se dinamiza en virtud del crecimiento -abstracto- del valor de cambio, y no propiamente de la satisfacción de necesidades concretas, la ciencia no se ocupa de los "objetos de la experiencia ordinaria", sino de abstraer de ellos fórmulas abstractas (Kracauer, 1960, p. 292). Apuntalada en una "abstracción" [Abstraktheit] que no incluye al ser humano (Kracauer, 2006, p. 266), dentro de la modernidad, los intereses humanos quedan relegados a un segundo plano. Con ello, la lógica del desencantamiento del mundo jalonada por el lluminismo resulta parcialmente revertida: en lugar de servir a la emancipación humana frente a los poderes míticos, la racionalidad instrumental habría adquirido un tipo de dinámica propia que somete todo ámbito de la existencia a su propia forma. Así, y en contravía de perspectivas como el historicismo o la metafísica ilustrada de la historia, Kracauer afirma que el proceso de desmitologización moderno desemboca en su opuesto. Escindida del mundo concreto, y convertida en una carcasa abstracta y totalizante (sin un fin más allá de sí misma), la racionalidad ilustrada termina reprimiendo sus potenciales progresivos, cayendo en el ámbito coactivo del mito. En ese mundo reencantado, los individuos experimentan el 
mundo social como si se tratase de un "proceso natural", no histórico, ni creado por ellos, que pesa sobre sus espaldas como una carga objetiva y hostil (Kracauer, 1995, p. 130). Naturalizado el presente (eternizado bajo la forma de lo siempre dado), la transitoriedad resulta reprimida, y la ocurrencia de lo enfáticamente nuevo, obturada. Como en el mito, en ese mundo se configura la imagen de una sociedad que carece aparentemente de afuera y que, como tal, nunca podría ser superada.

Frente al hiato abierto entre racionalidad y mundo corpóreo, cuyo corolario es la mutilación de la experiencia y la absolutización del ahora, Kracauer aboga por "redimir la realidad material, liberándola de las cadenas impuestas por un pensamiento abstracto, cosificado y cosificador" (Vedda en Kracauer, 2008, p. 243). La tarea de superación de ese estado de cosas, afirma, le impone a la conciencia la exigencia de reencontrar la concretud y determinación del mundo (Kracauer, 1995, p. 140). Esto supone consecuencias teóricas y metodológicas. Tributario de G. Simmel -a quien elogia por haber "abierto las puertas que conducen al mundo de la realidad", aproximándose a las cosas "pero sin poder integrarlas en una 'imagen total'” (Belke en Kracauer, 2008, p. 37)-, Kracauer critica la totalización conceptual, mediante el rescate de los elementos situados en la superficie [Oberfläche] del mundo moderno, desestimados por la tradición filosófica. Convencido de que solo puede alcanzarse lo incondicionado desde un punto de vista negativo, como reflejo de una realidad cosificada, su filosofía busca enfocarse en lo "genuino" que se oculta en "los intersticios entre las creencias dogmatizadas acerca del mundo" (Kracauer, 2010, p. 243). Su mirada busca las fisuras esquivas al ojo que privilegia la abstracción sobre lo concreto. A las restricciones del discurso racional, que "hace que las cosas se tornen uniformes dentro de sus rígidos armazones conceptuales", él les contrapone "la potencia subversiva de la analogía, que puede liberar a la realidad de sus 'grotescas petrificaciones conceptuales" (Zohlen en Vedda, 2013, p. 83). Kracauer se posa sobre esa superficie alienada, desatendida o subestimada por las críticas conservadoras y lapsarias de la modernidad, esas áreas marginales de la cultura de masas -tales como el cine, la 
fotografía, las calles, los espectáculos-, los cuales le sirven como indicadores de las más arraigadas paradojas de esa sociedad ${ }^{2}$.

En ese sentido, Kracauer comparte y extiende la idea lukácsiana acerca de la forma estética como vehículo de expresión que hace legible el momento histórico alienado (Lukács, 2010). Pero este retorno a las formas materiales y concretas que reverberan en la cotidianidad moderna inaccesibles para el pensamiento abstracto-, no pretende recomponer ninguna supuestamente perdida totalidad significativa (como sucede en Lukács). Por el contrario, haciendo justicia a la individualidad de sus objetos, ese movimiento implica una crítica de todo intento de aprehensión abstracto y totalizador del mundo social (Vedda en Kracauer, 2008, p. 243). A partir de una desconfianza frente al todo, esta tarea micro-lógica pretende vislumbrar las fibras que componen el presente (Kracauer, 1995, p. 140), sin desprender de allí derivaciones macro-lógicas que intenten aprehender y agotar lo múltiple en su conjunto, sino manteniendo dichas superficies como configuraciones inacabadas (Hansen, 1991, p. 51). Ese giro electivo hacia los fenómenos de superficie, hacia las trivialidades de la vida cotidiana que emergen anónima y discontinuamente, dispone de un momento político. El mismo corresponde a una estrategia de mirar más allá de lo inmediatamente dado, para desmitificar el mundo moderno, disolviendo su aparente naturalidad. Tal desmitificación no pasa por un rechazo unilateral de la modernidad. Aunque el reencantamiento del mundo operado por la ratio burguesa instaura una coraza coactiva que tiende a abarcar el mundo en su conjunto, Kracauer encuentra que en su inmanencia se alberga una potente promesa emancipatoria. Ni crítica lapsaria ni reacción romántica, su perspectiva asume que en el seno de la modernidad se verifica, no un exceso de racionalización, sino una falta de su radicalización. Si la ratio moderna resulta totalizante y mutilada (en cuanto que desinteresada de los seres humanos), ella dispone de un potencial que puede ser puesto al servicio de los seres humanos. Kracauer propone así una superación gestada desde la propia inmanencia del mundo racionalizado, que

2 W. Benjamin se refiere a Kracauer como un outsider que voluntariamente habita los márgenes, una suerte de "trapero" que recoge "trapos discursivos" y "jirones lingüísticos", desperdicios que no remiten a una unidad plena, sino a la fragmentariedad y desintegración del mundo moderno (Benjamin en Kracauer, 2008, p. 100). 
permitiría una reapropiación de los potenciales constituidos en él. En la naturaleza muda, desnuda y sin sustancia del mundo cosificado, Kracauer encuentra los resquicios de una emancipación social, que se traduciría en una correlativa emancipación de la conciencia (esto es, en la realización de una racionalidad plena [Vernunft], preocupada por la existencia de los seres humanos). La misma abstracción moderna ofrece los medios para redimir la realidad física, y pensar en la posibilidad de existencia de una realidad social liberada de los efectos opresivos imperantes en el presente. La tarea de inmersión dentro de las hendiduras del mundo cosificado tendrá por finalidad, de un lado, encontrar las huellas de una configuración histórica peculiar y, de otro, hallar en su propia inmanencia los destellos que conducirían hacia una transformación del mundo social. A los ojos de Kracauer, la vida cotidiana, ese contenedor temporal de los desechos de la modernidad, termina pues expresando la paradoja de una sociedad que, simultáneamente, aparece como locus en el que se verifica la pérdida de sentido del mundo en su estado actual y, simultáneamente, se cristaliza una promesa de transformación y mejoría.

\section{Cine y desintegración del presente.}

Según Kracauer, la vía para romper la petrificación del presente, esa eternización del ahora ocasionada por la abstracción moderna, es la experiencia de las cosas en su concreción (Kracauer, 1960, p. 298) ${ }^{3}$. El cine cumple un papel central en esta pretensión. Al registrar la cara visible del mundo, las películas constituyen "jeroglíficos visibles" -portadoras de "un peso sintomático"- de "la dinámica invisible de las relaciones humanas", y, por ende, de la vida interior de la sociedad de la que emergen (Kracauer, 1985, p. 15). El énfasis en la exterioridad que le resulta inherente representa una ventaja del medio cinematográfico, mediante el cual puede comprenderse dialécticamente la relación existente entre los contenidos del mundo interior y el mundo material

3 Kracauer no afirma una idea esencial o primigenia de experiencia que tendría que ser liberada de los velos impuestos por las formas de socialización modernas. La realidad no es para él un dato ontológico, que pudiese ser experimentado neutralmente: "solo podemos experimentar la realidad que se encuentra a nuestra disposición" (Kracauer, Theory of Film 297). Dentro de la multiplicidad de realidades posibles, "no todos esos mundos se encuentran igualmente disponibles para nosotros" (Kracauer, 1960, p. 298). 
moderno: “¿Quizás la vía hacia ellos, si existe tal, conduce a través de la experiencia de la realidad superficial? ¿Quizás, antes que un callejón sin salida o una mera distracción, el filme es una puerta?" (Kracauer, 1960, p. 287). Pero ¿a qué tipo de puerta se refiere Kracauer?, ¿a dónde lleva esa puerta?

En su Teoría del cine, Kracauer reviste al medio cinematográfico de un carácter crítico-social. Allí, afirma que el cine es esencialmente una extensión de la fotografía, y comparte con ella marcadas afinidades inherentes por el mundo visible: "[...] junto con la fotografía, el cine es el único arte que exhibe su material bruto"(Kracauer, 1960, p. 302 $)^{4}$. Sin embargo, aunque Kracauer enfatiza la prioridad que las tendencias "realistas" del realizador cinematográfico deberían tener frente a las tendencias "formativas", esto no supone afirmar el carácter especular del cine. No limitado a su carácter representacional, el cine no es un espejo neutral que registra el mundo físico. Su materia prima son fragmentos caleidoscópicos del mundo físico ordinario -muchas veces desapercibidos en la cotidianidad: "Sin ninguna noción consciente de su destino, el cine nos presenta un mundo de organismos, interpenetrados y mutuamente influenciados: y nos permite pensar en ese mundo con un mayor grado de concreción" (Mumford en Kracauer, 1960, p. 299). Desprovistos de una regulación trascendental, estos fragmentos son aislados, descompuestos y convertidos en material maleable, apto para la representación transfigurada. Entre los objetos del cine, Kracauer menciona los "fenómenos que figuran entre los puntos ciegos de la mente" de los que "la costumbre y los prejuicios impiden darse cuenta" (Kracauer, 1960, p. 53). Entre estos "puntos ciegos", se encuentran los "desechos" del mundo, revelaciones que le permiten al espectador experimentar cosas obliteradas por la conciencia en la experiencia cotidiana: "Muchos de los objetos pasan desapercibidos, simplemente porque nunca se nos ocurre mirar hacia donde están [...] aquello que normalmente preferimos ignorar resulta atractivo para [el cine] precisamente a causa de esta

4 Esa afinidad ya había sido destacada por Kracauer en Fotografía (2006). En Teoría del cine, Kracauer señala cinco afinidades inherentes entre cine y fotografía: el desorden, lo fortuito, la indefinición, lo indeterminado y el "flujo de la vida" (Kracauer, 1960, pp. 60-74). 
desatención común"; el filme puede "ofrecer a la cámara una amplia oportunidad para satisfacer su curiosidad y su función innata como hurgadora de desechos" (Kracauer, 1960, p. 53).

Esas afinidades con el mundo material permiten definir el potencial crítico del cine desde un doble punto de vista. Primero, el cine permite desnaturalizar el mundo en el que vivimos, socavar la esclerotización del presente. En una sociedad signada por la descorporización -intrínseca al proceso económico y al pensamiento científico-, en cuyo seno la realidad física resulta eludida y los individuos atomizados, el cine permite "superar las barreras que nos separan de nuestro entorno cotidiano" (Kracauer, 1960, p. 53). El cine puede interrumpir temporalmente la experiencia abstracta del sujeto frente al mundo objetivo, lo cual lo lleva a reconectarse con el mundo material y sus cualidades mediante un efecto de extrañamiento [estrangement] frente a la supuesta naturalidad del mundo cotidiano, es decir, el mundo tal y cual se ajusta a nuestros modos habituales (abstractos) de pensamiento y percepción. El cine permite alcanzar un estado de exilio. El espectador se convierte en un extranjero situado en el cuasi vacío de la extraterritorialidad, que puede sustraerse de la naturalidad del mundo, y ver su existencia anterior con los ojos de quien no es de la casa (Kracauer, 2010, p. 122). Esto potencia una nueva relación sensorial con el mundo material, permitiendo nuevos modos de experiencia mimética, identificación y sociabilidad (Hansen, 2012$, p. 4$)^{5}$.

Debido a la fragmentariedad expuesta por el cine $-\mathrm{y}$ del igualmente carácter fragmentario de la conciencia de un individuo inmerso en un mundo irreductible a un conjunto consistente-, el espectador nunca aprehende totalidades, sino "pequeños momentos de la vida material" (Kracauer, 1960, p. 303). Aunque el cine se organiza de acuerdo con una estructura diegética orientada -en la que confluyen pequeñas unidades extraídas de todo tipo de ámbitos imaginables, libremente articuladas por el realizador-, cada uno de los elementos que lo configuran pueden generar por sí mismos un impacto o cadena de reacciones en el espectador (desatar, por ejemplo, procesos de

5 Esto remite a la Peculiaridad de lo estético de Lukács, en donde este afirma que el arte no replica los objetos exteriores, sino que fomenta una mirada extrañada y distanciada que subyuga el modo habitual de contemplar el mundo, imponiendo un nuevo mundo, trayendo los objetos a la intuición como si no hubiera existido nunca una representación de ese objeto (Vedda, 2011, p. 180). 
memoria involuntaria). Si bien cada uno de esos elementos "pretende avanzar en la historia a la que pertenece, también nos afecta en gran medida, o incluso principalmente, como un momento fragmentario de la realidad visible, rodeado, por así decirlo, por una franja de significados visibles e indeterminados" (Kracauer, 1960, p. 303). La afinidad del medio fotográfico con lo indeterminado (Vedda, 2011, p. 172) hace que cualquier gesto singular pueda ser desacoplado del curso narrativo por parte del espectador. Detonando la ocurrencia de algún efecto sobre la subjetividad, que puede ser común a cada individuo, aunque meramente circunstancial o residual en términos de la diégesis que orienta a la película, el cine puede "producir un efecto tóxico" (Kracauer, 1960, p. 303). Terreno en el que se expresa la contingencia del mundo, el cine no absorbe plenamente al espectador en su propio campo de inmanencia narrativo, sino que lo estimula, una y otra vez, a salir de la imagen -en diferentes vías- y entrelazar sus elementos con contextos de la propia existencia; con ello, el espectador "oscila entre la auto-absorción y el auto-abandono" (Kracauer, 1960, p. 166).

A partir de esos desechos, al alcance de todos en cuanto que parte de la vida cotidiana aunque muchas veces desapercibidos-, se abre una amplia dimensión de sentido que va más allá de la "superestructura de la historia específica que los contiene", que incluso puede llegar a confrontar al espectador respecto de las ideas que tiene del mundo, o ponerlo frente a sus peores temores (Kracauer, 1960, p. 303). El cine posibilita tomar una suerte de distancia frente al presente, permite discernir el hechizo que ejerce la modernidad, asumir críticamente la primacía del presente que ella misma impone, y así ubicarla como un tipo de configuración naturalizada (Kracauer, 2010, p. 52). A través del cine, el elemento natural pasa a ser definido desde su eterna caducidad, como una finitud más entre finitudes que, en su carácter pasajero, se sustrae de todo campo de inmanencia impuesto o derivado de cualquier idea de invariabilidad. Lejos de ser una instancia inapelable, en el mundo social naturalizado se transluce ahora la historia en su transitoriedad, como lugar del acontecimiento, ámbito de la emergencia de lo cualitativa e irreductiblemente nuevo. El cine expone al mundo que habitamos como ámbito de la finitud que no permanece, de lo finito que se renueva. Él muestra que toda naturaleza es eternamente caduca, por lo tanto, siempre diferente. A medida que los objetos en movimiento en la pantalla parecen transformarse en algo distinto de lo 
que aparecían, mediante interrupciones, cortes, aislamientos, extensiones y magnificaciones, la mimesis psicofisiológica permitida por el cine le proporciona al espectador la sensación de participar en esta transformación, evocando la posibilidad -a la vez amenazadora y liberadora- de diluir, momentáneamente, las estructuras fijas del mundo social. Aquí Kracauer comparte con Benjamin la idea según la cual el cine, como inventario del mundo circundante, incrementa, por un lado, "la comprensión del transcurso forzoso por el cual está regida nuestra existencia, llega, por otro lado, a asegurarnos márgenes de maniobra enormes e insospechados" (Benjamin, 2019, p. 85). Aquél dinamita la solidez del mundo, de modo que "ahora nosotros emprendemos tranquilamente aventureros viajes entre sus vastamente dispersas ruinas" (Benjamin, 2019, p. 86).

Según Kracauer, la experiencia cinematográfica no solo apunta a la disolución de la cosificación patente en el mundo objetivo, sino de su, igualmente cosificado, correlato subjetivo. Al representar el mundo material en movimiento en su dimensión fortuita y efímera, "como si se la captara en route" (Vedda, 2011, p. 177), el cine se involucra con el individuo corpóreo y sensible "con piel y pelo" (Hansen, 2012, p. 262), diferente del sujeto abstracto. La experiencia cinematográfica permite minar la idea del sujeto soberano, idéntico a sí mismo. En esa dirección, Kracauer se refiere a las "correspondencias psicofísicas" existentes entre el mundo objetivo presentado en la película y el sujeto al que se revela este mundo. El ser humano es esencialmente un ser físico, enraizado en el mundo material y concreto. Al afectar los sentidos del espectador, "comprometiéndolo fisiológicamente [respuestas cenestésicas] antes de que se encuentre en posición de responder intelectualmente", debilita su conciencia, aquieta su espíritu (Kracauer, 1960, p. 158). Este tipo de experiencia no es propiamente de identificación con los personajes o con la narración sino, más bien, describe, desde un punto de vista somático y preconsciente, una forma mimética de identificación que disocia el yo del espectador: "[l]a tenaz insistencia de Kracauer en la prioridad de la realidad física dispone, sobre todo, de un sentido negativo, es decir, tiende hacia la negación del principio de autoafirmación del sujeto" (Schlüpmann, 1991, p. 123). Como espectador de cine, "el yo como impulso primario de los pensamientos y decisiones renuncia a su poder y control", y termina por disolverse la identidad individual (Kracauer, 1960, p. 159). 
A partir de la idea de ensoñación, Kracauer intenta mostrar cómo en el cine las relaciones entre sujeto y objeto se definen a través de una peculiar dialéctica. De un lado, acudiendo al filósofo francés, Lucien Sève, Kracauer introduce la primera categoría de soñar "hacia el objeto" [dreaming toward the object], y sugiere que, en un nivel fenomenológico básico, la imagen cinematográfica perturba más bien que afirma nuestras preconcepciones frente a los objetos. La idea de un espectador que se encuentra en un estado de ensoñación [between waking and sleeping] permite pensar al objeto cinematográfico como un agente activo que produce dicho efecto -incluso pudiendo llegar a direccionar dicha ensoñación-, y no simplemente como algo que está dado para ser dispuesto por parte de un sujeto que lo domina a placer. Teniendo en cuenta que el espectador se "dirige a la deriva hacia y dentro de los objetos", y es llevado por el mundo material hacia "búsquedas inagotables" más llenas de inquietudes que de certezas (Kracauer, 1960, p. 165), la experiencia cinematográfica suspende el hiato entre sujeto y objeto. Kracauer asume que la representación cinematográfica de las cosas se vincula más con emociones subjetivas acompasadas por el objeto, aunque no circunscritas a él. La capacidad fisiognómica del cine ofrece un modo de experiencia somática que difumina las distinciones analíticas entre sujeto y objeto, facilitando así que las cosas aparezcan en su alteridad. El debilitamiento del yo saca a flote experiencias subconscientes o inconscientes del espectador, frente a las que el cine opera como "chispa de ignición", facilitando la organización alternativa de sus elementos (Kracauer, 1960, p. 165). El doble movimiento resulta, pues, inseparable. La secuencia cinematográfica conduce al espectador lejos de la imagen dada, llevándolo hacia recuerdos involuntarios; la imagen misma retrocede después de haber movilizado sus temores y deseos previamente reprimidos.

Según Kracauer, debido a la forma en la que plantea enfrentamientos frente a mundos desconocidos o ignorados, el cine, en su apertura, induce al espectador a ceder el control consciente o intelectual, y a conectarse a las imágenes presentadas en un nivel más visceral. El medio cinematográfico "lleva al espectador lejos de la imagen dada hacia ensueños subjetivos [...] Una vez el yo organizado del espectador se ha rendido, sus experiencias subconscientes o inconscientes, temores y esperanzas tienden a salir y tomar el mando" (Kracauer, 1960, p. 165). El 
cine deviene vía de encuentro con la alteridad y la finitud de la existencia, un contacto mediado respecto de un mundo en el que, aunque al alcance de todos: "no vemos ni podemos ver los horrores actuales porque nos paralizan con un miedo enceguecedor" (Kracauer, 1960, p. 303). Sus imágenes reproducen la apariencia de estos horrores, permitiendo llevarlos a la conciencia. Aquellas suponen, entonces, un efecto especular de carácter negativo; reflejan acontecimientos cuyo contacto directo en la vida real produciría un efecto petrificante. En ese sentido, la pantalla de cine opera como "el escudo reluciente de Atenea" (Kracauer, 1960, p. 303). Al igual que en el caso de Perseo, para quien el escudo cumple con la finalidad de permitirle ver a la terrible Medusa indirectamente y así lograr decapitarla, la imagen en la pantalla induce al espectador a enfrentar el horror reflejado, a experimentar la atrocidad de la realidad sin quedar paralizado, a grabar en su memoria el rostro de aspectos de la vida que son demasiado horribles para ser vistos directamente (Perivolaropoulou, 2004, p. 39). Pero, en el mito, la decapitación no pone fin al poder de Medusa. Perseo lleva su cabeza a Atenea, quien la utilizará para aterrorizar a sus enemigos. Perseo, el observador de imágenes, no logra vencer definitivamente el fantasma. El mayor logro de Perseo no es, pues, decapitar a Medusa, sino superar sus miedos y mirar su reflejo en el escudo, lo cual, precisamente, le permitió decapitarla. De la misma forma, el cine hace que:

En la vivencia de las filas de cabezas de terneros ${ }^{6}$ o la camada de cuerpos humanos torturados en las películas hechas de los campos de concentración nazis, redimamos el horror de su invisibilidad tras los velos del pánico y la imaginación. Y esta experiencia es liberadora en la medida en que elimina un tabú más potente (Kracauer, 1960, p. 303).

El cine "ayuda a pensar a través de las cosas y no por encima de ellas" (Kracauer, 2010, p. 220). El espectador no solo experimenta los aspectos de la realidad física como hechos brutos, sino que, más bien, experimenta a través de ellos su significado humano, y las huellas de la vida humana que se pueden encontrar allí. Enfrentando al espectador con su enraizamiento en la desesperación física, el cine conecta ideas que se han vuelto abstractas y aparentemente escindidas del mundo

6 Kracauer se refiere a Le sang des bêtes (1949), película de Georges Franju. 
concreto en el que se fundan plenamente y tienen toda su realidad, y en el que no cesan de dejar sus marcas. El cine contribuye a taladrar la abstracción y ver de frente la contracara de la Ilustración. Aquí sale a la luz el segundo momento que Kracauer le atribuye a la potencialidad crítica del cine, vinculado no ya con su efecto corrosivo respecto de la naturalidad del mundo, sino con las posibilidades de su efectiva transfiguración.

\section{Cine y transfiguración utópica.}

Para Kracauer, el cine se constituye como un espacio contingente, abierto a la aleatoriedad, a interacciones fugaces desde las que se articulan constelaciones siempre renovadas. A diferencia, por ejemplo, de la tragedia, que se mantiene en la inmanencia mítica configurada como "un cosmos finito y ordenado", el cine "debe tender hacia la expansión de nuestra realidad -un mundo indefinido e ilimitado" (Kracauer, 1960, p. x). Mientras que la tragedia corresponde a un mundo clausurado en donde el destino vence al azar, el cine es un flujo aleatorio "de eventos en el que se ven envueltos, por igual, humanos y objetos inanimados" (Kracauer, 1960, p. x). Debido a esa flexibilidad, el cine no solo permite percatarse de los elementos cotidianamente obviados del mundo material, sino ampliar sus horizontes. Al abrir los confines de la experiencia, las películas "virtualmente hacen del mundo nuestro hogar" (Kracauer, 1960, p. 304). El espectador ve las imágenes en la pantalla en un estado semejante a la ensoñación [dream-like state]; en ella aprehende la realidad física en su concretud, experimenta un flujo infinito de contingencias y de eventos -sustanciales e insustanciales- cambiantes, objetos dispersos y formas indescriptibles, "lo fugitivo, lo indeterminado, lo amorfo, lo singular, lo que no tiene nombre" (Agard, 2016, p. 247) ${ }^{7}$. Contra la consideración adorniana, para quien el medio cinematográfico no revela ni altera la fantasmagoría y el sufrimiento (Gilloch, 2015, p. 190), Kracauer ve en el cine un medio que permite reconectar al ser humano con aquello que le resulta cotidianamente negado en el seno del mundo

\footnotetext{
7 Kracauer hace eco de Benjamin, para quien, mediante un sinnúmero de mecanismos, el cine muestra configuraciones estructurales completamente nuevas de la materia; en los motivos del mundo ya conocido descubre otros completamente desconocidos, peculiarmente resbaladizos, flotantes, sobrenaturales. Ante una dimensión consciente, el cine abre el saber "del inconsciente óptico" (Benjamin, 2019, p. 86).
} 
racionalizado. Al ofrecer el mundo de la vida [Lebenswelt] en su incompletud, el espectador encuentra en el cine la vida plena que la sociedad le niega (Kracauer, 1960, p. 165) -“la imagen de la utopía y su imposibilidad" (Hansen, 2012, p. 265)-, el mundo como "dado y no dado" (Kracauer, 1960, p. 268), pero también “la comprensión de que el mundo 'podría ser diferente y aún seguir existiendo" (Hansen, 2012, p. 265).

Según Kracauer, más allá de alienar al espectador desde el mundo cotidiano y familiar, el cine ayuda a experimentar nuevos tipos de sensaciones subjetivas, o actitudes hacia el mundo material. Desarrollado a partir de la fotografía, el cine tiene funciones similares y comparte sus mismas determinaciones. Si la revelación del mundo humano como fragmentado, transitorio y en ruinas se logra mediante la fotografía, el cine dispone de esta misma tendencia, yendo aún más lejos. Mientras que la fotografía contribuye a la desintegración de un mundo [Weltzerfall] que parecía que era familiar, el cine es la tecnología que intenta reunir nuevamente estos elementos de una manera significativa. Como afirma M. Hansen, "[s]i la fotografía refleja el detritus de la historia como simple desorden, el cine tiene la posibilidad de avanzar sobre este desorden" (Hansen, 1991, p. 56), reordenando los elementos materiales que graba, y reconfigurando los elementos del mundo tal como se nos presentan.

Dotado de una vocación transfigurativa, el cine hace patente la posibilidad de redimir el mundo cosificado. Refiriéndose a una visita a las instalaciones de UFA, Kracauer afirma que éste es un mundo "hecho de papier-mâché", en donde todo es completamente innatural y todo es exactamente como la naturaleza (Kracauer, 1995, p. 281). Las cosas que lo habitan "no pertenecen a la realidad. Son copias y distorsiones que han sido arrancadas del tiempo y confundidas. Se quedan inmóviles, llenas de significado desde el frente, mientras que desde la parte trasera son una nada vacía. Un mal sueño sobre objetos que han sido forzados a entrar en el reino corpóreo" (Kracauer, 1995, p. 281). Allí los poderes mitológicos, apilados como las ruinas del universo, se convierten en divertimento. Cada objeto está como sustraído del flujo del tiempo, congelado y escindido del mundo: "Aquí todos los objetos son solo lo que se supone que representan en este momento: no conocen ningún desarrollo con el tiempo" (Kracauer, 1995, p. 283). Cada objeto, 
separado de las relaciones con los demás, parece refractario a los efectos de la historia: "[I]os dueños de este mundo muestran una gratificante falta de sentido de la historia", construyen y destruyen culturas a su antojo (Kracauer, 1995, p. 283). Para ellos, nada existe para perdurar. Toda creación apunta, de antemano, a su demolición. Aquí es imposible prever qué configuración vendrá en el futuro, "[I] as leyes de estas metamorfosis son insondables" (Kracauer, 1995, p. 283). En este reino de la arbitrariedad, el mundo real no es un límite; mediante el uso de innumerables efectos que crean ilusiones desde las ilusiones, éste se desplaza en múltiples direcciones y temporalidades, haciendo de la realidad un producto inacabado. Ese mundo cósico revela sus secretos solo delante de la cámara. El montaje cinematográfico teje una almazuela de calicós, en el cual a cada fenómeno le corresponde un plano peculiar, cuya juntura termina por constituir una heterogénea red de interpretaciones que nunca resultan definitivas (Díaz, 2015, p. 190). Antes que dejar el mundo en su estado fragmentado, cada elemento deviene piedra de un mosaico, parte de un mundo reconfigurado. Los objetos antes separados de todo contexto son ahora reinsertados en un cosmos policéntrico, "su aislamiento borrado y su mueca suavizada" (Kracauer, 1995, p. 287). Sacados de sus tumbas, las ruinas del mundo cosificado despiertan a una vida que no sigue un curso lineal o secuencial; ellos "son tamizados, empalmados, cortados, y etiquetados hasta que finalmente del enorme caos emerge un pequeño todo" (Kracauer, 1995, p. 288).

A partir de aquí, Kracauer le atribuye al cine la capacidad de dirigirse hacia la utópica "organización válida de las cosas", que ya había postulado como la tarea del pensamiento en el ensayo Fotografía: "[l]as capacidades del cine en términos de desplazamientos y disyunción, de figuración y desfiguración, albergan una posibilidad utópica, fiel a la tradición mesiánica” (Hansen, 1991, p. 56). El cine no solo representa y revela lo que ha grabado con una fidelidad sin precedentes, sino que también permite la reconfiguración crítica del material visual (Gilloch, 2015, p. 190). Él posibilita una "iluminación profana, de un encantamiento que sirve para desencantar" (Gilloch, 2015, p. 191). Debido a que puede reacoplar los elementos del mundo objetivo, el cine representa un modo paradigmático de experiencia - de encuentro y descubrimiento- del mundo inmerso en una crisis histórica, que apunta más allá de ella. Estos efectos del cine tienen que leerse 
como potencialidad y no como efectiva realidad, como una consideración prescriptiva sobre lo que el cine podría llevar a cabo, bajo las condiciones sociales existentes, en términos de las posibilidades de auto-alienación y modos alternativos de interacción con el mundo material (Hansen, 2012, p. 263).

El cine, como el medio fotográfico, se justifica solo en cuanto que, como un hilo de Ariadna, permite hacer algo mejor que otras cosas: "ir hasta el límite al registrar y penetrar la realidad física" (Kracauer, 2010, p. 97). Exceptuando sus usos meramente ideológicos o puramente artísticos, en los que la idea preconcebida se proyecta desde arriba hacia la materialidad con intenciones de moldearla, Kracauer afirma que el cine: "está materialistamente orientado; procede de abajo hacia arriba" (Kracauer, 1960, p. 309). Al permitir la revelación del mundo material con sus correspondencias psicofísicas, en cuanto que "animado por el deseo de retratar la vida material más transitoria, la vida en lo que tiene de más efímero" (Kracauer, 1960, p. ix), el cine es un canal para promover la redención de la realidad física. Sus imágenes permiten "llevarnos con nosotros los objetos y ocurrencias que comprende el flujo de la vida material" (Kracauer, 1960, p. 300). Aquí, la idea de revelación no significa mero develamiento, sino que dispone de un sentido escatológico, como prefiguración de una renovación de la naturaleza. Rescatando la realidad material, el cine consuma, al mismo tiempo, "una resurrección medial del cuerpo, y funciona, de ese modo, casi como un médium del día del Juicio Final, en el que el mundo es reordenado y traspuesto a su estado originario" (Butzer en Vedda, 2011, p. 177).

El cine resulta ahora vinculado, no con la creación de totalidades, ni con la circunscripción y determinación del sentidos plenos y transparentes que esto conlleva, sino con una tendencia hacia la desintegración y la contingencia que le son, simultáneamente, inherentes. Esta simultaneidad expresa la paradójica relación existente en la modernidad entre la coacción y la emancipación. El cine facilita el acercamiento al presente cosificado, y expone su fragmentariedad y contingencia $-\mathrm{y}$ por ende su transitoriedad-, haciendo visible -con toda la carga sensorial y corpórea que esto implica- las contradicciones más profundas de la modernidad. A partir de allí es posible comprender que, si bien a esta sociedad le resulta inseparable, desde sus propios cimientos, una forma sistémica 
de alienación, una sustitución de la naturaleza, ahora devenida coacción social, también le es intrínseca la posibilidad de superar dicho estado, permitiendo pensar en las posibilidades de entablar tipos diferentes (superadores) de relación de la conciencia frente a la naturaleza. En lugar de ofrecer una vía hacia la reminiscencia de momentos anteriores -incluso no vividos por la conciencia- hacia los que el espectador sería transportado, el cine irrumpe abruptamente en el presente, como señal, tanto de la propia fugacidad física del espectador, como de la de todas las configuraciones dadas -sociales, políticas, económicas, culturales etc. En última instancia, el cine se sitúa en un umbral entre aquél mundo muerto y cosificado, y sus posibilidades de superación, abriendo las puertas hacia "un rescate de la existencia material, contra la abstracción engendrada por el proceso de racionalización del mundo" (Traverso, 1998, p. 205).

Cuando Kracauer se refiere al mundo como "indeterminado al significado" (Kracauer, 1960, p. 68), afirma una ausencia de sentido definitivo. Fruto de la tensión entre el automatismo de la cámara y la mirada del espectador, el cine es capaz de encontrar ese carácter indeterminado del mundo, al tiempo que permite su configuración como unidad, convirtiéndolo en un horizonte de posibilidades $^{8}$. El momento corrosivo del cine abre el camino a una posibilidad de recomposición general de un mundo que ha alcanzado un punto extremo de desorganización. Según Kracauer, este podría ser el papel del cine: socavando la realidad cosificada, prefigurar un orden alternativo, un mundo social recompuesto. Despojar al mundo de un sentido ulterior significa una ganancia, pues un mundo sin significado abre las puertas de las significaciones. Dejar de lado el significado nos libera de la idea de una supuesta auto-suficiencia del mundo en su estado actual.

$8 \mathrm{El}$ análisis kracaueriano encuentra eco en pensadores contemporáneos como J. Ranciére. Éste se refiere a la "fábula frustrada" que está en el corazón del cine "cuyo principio básico es la unificación del pensamiento consciente y la percepción inconsciente". Para Ranciére, como la vida, el cine presenta situaciones abiertas a todas las direcciones, debido a la conjunción de dos "inteligencias", la del realizador que busca desarrollar una trama, y la del mecanismo de la cámara que no construye historias, sino que registra infinidad de micro-movimientos, ajenos a toda trama y desenlace. Esto no implica que la cámara registre la identidad de la realidad, sino, más bien, que ella transforma el estatuto mismo de la realidad. La cámara registra las cosas tal como no las ve el ojo humano. A partir de ahí, Ranciére afirma la inversión operada por el cine respecto de la jerarquía mythos-opsis, el primero como racionalización de la trama y el segundo como efecto sensible en el espectador, permitido por la apertura que ofrece la cámara (Rancière, 2001, pp. 7-11). 
La perspectiva kracaueriana no busca descubrir sentidos ulteriores, ni proveer ninguna teoría sistemática o definitiva, refiriendo sus observaciones a digresiones frente a sus objetos (Gilloch, 2015, p. 189). El conocimiento que resulta de este giro en términos del acercamiento frente al mundo, que toma por objeto aquello que aparece como inadvertido, no puede concebirse como "modelo de ninguna teoría", sino, más bien, como "casos ejemplares de la realidad" (Kracauer, 1998, p. 26). Esto supone que "el significado de los fenómenos mismos ya no está dado o aún no está definido; son síntomas que necesitan ser observados, descritos, descifrados e interpretados" (Hansen, 2012, p. 25). Antes que convertirlas en proposiciones teóricas autoreferenciales y abstractas, sin conexión con el mundo material, Kracauer le asigna al conocimiento de estos residuos una función práctica; ésta no es solo "la precondición para todo cambio, sino que realmente conlleva un cambio: una vez la situación en cuestión es exhaustivamente conocida, se debe actuar sobre la base de este nuevo conocimiento" (Kracauer, 1998, p. 25). El objetivo de tal movimiento no es meramente estético ni especulativo. Los restos de esta desintegración se abren como caminos posibles hacia la transformación de la realidad. En esa tarea emprendida por Kracauer, la de un "trapero, al amanecer: en la alborada del día de la revolución" (Kracauer, 2008, p. 101), los elementos hallados en la superficie devienen indicios que señalan un camino hacia la transformación que se espera que tenga lugar, si bien no se tenga claro el momento de su ocurrencia (Kracauer, 1995, p. 140). Filosofía que incluye, como en Benjamin, la posibilidad de “predecir el futuro a partir de la borra del café" (Vedda, 2013, p. 81), en Kracauer, el problema de la crítica tiene que ver, pues, con una preocupación por vislumbrar los tejidos que enhebran el conjunto de los intereses de la vida moderna, no para construir, confirmar o reforzar un sistema conceptual, sino para mostrar que aquéllos:

[...] tan incoherentes en la superficie, terminan por haber servido en una dirección, [...] a un solo propósito: la rehabilitación de objetivos y modos de ser que aún no tienen un nombre y por lo tanto son pasados por alto o juzgados erróneamente. (Kracauer, 2010, p. $52)$. 


\section{Cine, apertura de la historia y "pensamiento de la antesala".}

El de Kracauer es un esfuerzo por pensar que las condiciones bajo las que se define actualmente una suerte de cerrazón del mundo no resultarían definitivas. Recuperando la historia contenida en los objetos del mundo, su transitoriedad, el cine se convierte en un medio de iluminación profana y un arma para una crítica política explosiva (Gilloch, 2015, p. 192). El alcance de esa iluminación profana será expresado en su última obra, Historia, las últimas cosas antes de las últimas, en donde afirma la correlación existente entre medio cinematográfico e historia. Ambas, sostiene, se caracterizan por su carácter discontinuo e incompleto. Ni cine ni historia pueden ser agotados definitivamente; ambas escapan a toda pretensión totalizante. Dotados de un carácter transitorio, igual que el material del que se ocupan, ninguno de las dos puede pretender alcanzar una verdad última. De allí que ambos terrenos puedan definirse como áreas de antesala (Kracauer, 2010, p. 218). Pensadas desde un ideal del viaje que no arriba a ningún sitio (Agard, 2016, p. 162), cine e historia nunca alcanzan las "últimas cosas", sino que se enfocan en "las últimas cosas antes de las últimas" (Kracauer, 2010, p. 220).

El universo sociohistórico, en gran medida, elude ser captado por leyes, ya sea naturales o filosóficas: "[I]os asuntos humanos, [...] trascienden la dimensión de las fuerzas naturales y los patrones determinados en forma causal" (Kracauer, 2010, p. 74). Contra todo sistema sofocantemente cerrado, que cancela las causas perdidas, las posibilidades no realizadas, para Kracauer, la historia constituye "un material que es por largos períodos incipiente, heterogéneo, oscuro. Gran parte de éste es una masa opaca de hechos" (Kracauer, 2010, p. 76). Poniendo en cuestión ese imperativo teleológico que lleva hacia las últimas cosas, el pensamiento de Kracauer se hace elusivo tanto frente a las narrativas uniformes del progreso y a la auto-afirmación metafísica de la superioridad del presente, como frente a la rendición supuestamente anti-teleológica ante un contingencialismo dependiente de formas veladas de "últimas cosas". Acercarse a las "últimas cosas antes de las últimas" significa sumergirse en la historia, tal como lo permite el cine, desde su asistemática particularidad. Esta rehabilitación de las entidades singulares, del detalle, de lo 
discontinuo, permite liberar nuevos regímenes de sentido, irreconciliables con las significaciones generales y cerradas propuestas por los grandes relatos históricos, fundadas en una visión global de las acciones humanas (Despoix \& Schöttler, 2006, p. 209).

Como el cine, para Kracauer, la historia no se asienta sobre un cosmos ordenado. Ambos resultan más próximos a la infinitud azarosa e indeterminada de la Lebenswelt que a la abstracción; comprenden "objetos inanimados, rostros, multitudes, gente que se entremezcla, sufre y espera" (Kracauer, 2010, p. 100). Al tematizar la vida en su plenitud, la vida en sus variopintas formas de expresión cotidiana, el cine no pretende, primordialmente, ofrecer grandes construcciones de absolutos o de abstracciones universales. Él abre la posibilidad de dar cuenta de la contingencia histórica, una tarea en la que, como ocurre con la fotografía, el material no es consumido íntegramente (Machado \& Vedda, 2010, p. 20). Realidad de la cámara y realidad histórica se encuentran en un estado de semi-cocción [half-cooked state] que señala permanentemente hacia el "umbral" de posibles sentidos inexplorados. Análoga a los "grandes planos" de la fotografía o del cine, a "la óptica no humana de la cámara", la historia aparece como ambivalente, estructurada y, simultáneamente, sin forma acabada (Despoix \& Schöttler, 2006, p. 18).

Historia y medio cinematográfico, muy a pesar de la aparente continuidad que expresan continuidad de los acontecimientos, continuidad de las imágenes-, comparten un espacio para la contingencia y espontaneidad, en el que se prefiguran fisuras libres de sentidos impuestos heterónomamente y con antelación -en el caso de la historia, impuestos por el filósofo o historiador, y, en el caso del cine por el realizador-, las cuales permanecen abiertas a la creación de nuevos significados, prefigurando con ello puertas para la redención del mundo cosificado (Díaz, 2015 , p. 19). Contra la injustificada confianza en el alcance ilimitado del concepto filosófico, la perspectiva kracaueriana de la antesala, prefigurada por su comprensión del cine, aboga pues por una percepción de la estructura no homogénea ni definitiva del mundo sociohistórico. Con ello se abona el terreno para darle voz a las posibilidades no realizadas y olvidadas, a esas posibilidades innominadas que se encuentran a la espera de su redención desde las inevitables fracturas que quebrantan la ilusoria cerrazón de las verdades universales. La forma de acceder a esas 
posibilidades escondidas no pasa por su deducción a partir de un principio o verdad ulteriores, sino que puede surgir "de la concentración en configuraciones de particulares" (Kracauer, 2010, p. 240). Así, una vez que la misma racionalidad que se pretende auto-fundada y auto-suficiente se hace consciente de su propia limitación, se hacen visibles, desde la penumbra de esa historia de los vencedores y del progreso que la acompaña, que escamotea a los individuos derrotados y fallidos, las semblanzas borrosas de quienes la impugnaron y desmintieron, ahora vindicados tardíamente por obra del recuerdo. En última instancia, al concebir que el pasado dispone de un exceso de momentos para redimir, la perspectiva kracaueriana contiene un impulso ético-político de traer a la luz los escondidos y olvidados actos de opresión, para encontrar una suerte de justicia memorial.

En suma, a partir de las potencialidades de extrañamiento ofrecidas por el medio cinematográfico, el planteamiento kracaueriano abre una perspectiva diferente en cuanto a la consideración de la relación entre historia y memoria que desemboca en la configuración de un tipo de "memoria histórica sui generis", un espacio intersticial-aplicable a la realidad sociohistórica, a su experiencia y transformación- constituido por la integración de la experiencia del espectador, entre memoria individual y memoria colectiva, saber histórico y experiencia vivida (Machado \& Vedda, 2010, p. 65). En ese sentido, el cine podría ser el presagio de una apropiación viva de la historia por parte de los seres humanos, que daría sentido a este mundo disociado, apuntando a la posible existencia de un mundo social en el que aquéllos no sean ya dominados por sus propias abstracciones, a la manera de entidades metafísicas y aparentemente trascendentes que se les imponen sin consideración a sus propios intereses y diferencialidades.

\section{Conclusión.}

En su búsqueda por comprender los efectos desatados por el proceso de racionalización moderno, Kracauer opta por una mirada intersticial que toma como objeto lo inadvertido, esos desechos materiales del mundo social, tradicionalmente desestimados por la mirada filosófica. Reacio a alcanzar una verdad última o a construir una teoría sistemática, Kracauer dirige la mirada hacia las más anodinas expresiones del mundo cotidiano, escarba en la "basura de los hechos" (Kracauer, 
2010, p. 126), para comprender los rasgos determinantes y las contradicciones más arraigadas sobre las que se asienta la modernidad. A partir de allí, y en contravía de la teleología ilustrada de la historia, que sitúa el presente moderno como momento cumbre de un proceso lineal e irreversible de desmitificación, Kracauer afirma la recomposición en su seno de un mundo mítico, en el que los seres humanos son coaccionados por fuerzas heterónomas, abstractas y anónimas, en apariencia naturales y ajenas a sus propios intereses.

La teoría crítica imbrica dos momentos. Uno vinculado con la realización de un diagnóstico explicativo del presente y otro con la prefiguración utópica anticipatoria (Fraser, 2007, p. 207). Ambos momentos deben articularse desde una posición de inmanencia desde la cual se elabora la crítica, y no desde una posición transhistórica, válida para todo momento. En esa dirección, Kracauer convierte al medio cinematográfico en un instrumento de conocimiento crítico, desde un doble punto de vista. Según él, de un lado, el cine es un medio simultáneamente sensorial y reflexivo que se adapta de manera única a capturar la continua desintegración del mundo. Sus imágenes permiten vislumbrar las huellas del desgarramiento e incompletud de esta sociedad, desnaturalizando el presente, y rompiendo su petrificación. Acercándonos a la materialidad del mundo, el cine permite entrever la caducidad de todo aquello que se afirma como natural y acabado. Agrietando toda forma de totalización, simultáneamente, permite captar el mundo material en su carácter azaroso. Sus imágenes liberan al pensamiento de las amarras de la abstracción y los sentidos fijados. Su lógica de funcionamiento no obedece a secuencias predeterminadas o trascendentes, sino a fragmentos temporales que le permiten al espectador convertirse en un extraterritorial frente al mundo que habita, pudiendo experimentar la plena dispersión de su propio mundo cotidiano. El cine eleva la distancia entre sujeto y objeto, y despierta emociones que llevan a cuestionar el estado actual del mundo. Exponiéndolo como ruina, el cine señala el carácter desacralizado de la modernidad, convirtiéndose en mímesis de su negatividad.

Desde ese registro en negativo, el cine alcanza un segundo momento crítico, referido a la recomposición dinámica del mundo social. Kracauer insiste en que el mundo cosificado no es unilateralmente opresivo. Él alberga en su seno un momento emancipador, una posibilidad siempre 
abierta de reconfiguración del orden del mundo a partir de sus propios sedimentos. Reuniendo fragmentos alrededor de la nada, el cine muestra que el mundo no está cerrado, que el orden de las cosas puede ser alterado. Su afinidad con lo indeterminado permite desacoplar cada elemento del curso narrativo, incitando a pensar que el mundo podría realmente ser otra cosa, completamente diferente a lo que es en el presente. El cine abre así un espacio para la contingencia y espontaneidad, en el que se prefiguran fisuras libres de sentidos impuestos heterónomamente. Aquél permite la reconfiguración alternativa del tiempo y del espacio, convirtiéndose en un instrumento crítico-cognitivo desde el cual es posible prefigurar una alternativa al mundo reificado, en el que la primacía de la abstracción desencarnada ceda el paso a la primacía de los intereses humanos. Así, el cine -bisagra entre la segunda naturaleza y un posible futuro mundo redimidodeviene medio de expresión de un sentido escatológico, según el cual la modernidad podría ser superada -y superarse a sí misma- solo mediante la plena realización de todo su potencial desintegrador. En suma, y debido a la afinidad de la cámara con lo indeterminado, el cine se convierte en un medio privilegiado de iluminación disruptiva frente a la petrificación de la historia, cuyo corolario es la parálisis del presente. Permitiendo la confluencia de memoria individual y colectiva, saber histórico y experiencia vivida, el medio cinematográfico permite acercarse a la transitoriedad de los fenómenos del mundo cosificado, señalando hacia un horizonte en el que se entreven múltiples posibilidades de reconfiguración del universo sociohistórico, en términos de su redención frente al olvido y la muerte

\section{Referencias}

Adorno, T. W. (2003). Notas sobre Literatura. Obra completa. Tres Cantos: Akal.

Agard, O. (2016). Cinéma et modernité chez Siegfried Kracauer. Bulletin d'Analyse Phénoménologique, 4, pp. 228-248.

Benjamin, W. (2019). La obra de arte en la época de su reproductibilidad técnica. Buenos Aires: Ediciones Godot. 
Despoix, P., \& Schöttler, P. (2006). Siegfried Kracauer, penseur de I'histoire. París: Presses Université Laval.

Díaz, S. (2015). Historia y teoría crítica. Lectura de Siegfried Kracauer. Madrid: Biblioteca Nueva.

Elsaesser, T. (2014). Siegfried Kracauer's affinities. NECSUS. European Journal of Media Studies, 3(1), pp. 5-20.

Fraser, N. (2007). Identity, exclusion, and critique: a response to four critics. European Journal of Political Theory, 6(3), pp. 305-338.

Gilloch, G. (2015). Siegfried Kracauer. Cambridge: John Wiley \& Sons.

Hansen, M. (1991). Decentric perspectives: Kracauer's early writings on film and mass culture. New German Critique (54), pp. 47-76.

Hansen, M. (2012). Cinema and Experience: Siegfried Kracauer, Walter Benjamin, and Theodor W. Adorno (Vol. 44). Berkeley: Univ of California Press.

Harbord, J. (2007). Contingency's Work: Kracauer's Theory of Film and the Trope of the Accidental. New Formations (61), pp. 90-103.

Kracauer, S. (1960). Theory of film: the redemption of physical reality. New York: Oxford.

Kracauer, S. (1985). De Caligari a Hitler: historia psicológica del cine alemán. Barcelona: Paidós.

Kracauer, S. (1995). The mass ornament: Weimar essays. Massachusetts: Harvard University Press.

Kracauer, S. (1998). The salaried masses: Duty and distraction in Weimar Germany. Londres: Verso.

Kracauer, S. (2006). Estética sin territorio. Murcia: Colegio Oficial de Aparejadores y Arquitectos Técnicos.

Kracauer, S. (2008). Los empleados: un aspecto de la Alemania más reciente. Barcelona: Gedisa.

Kracauer, S. (2010). Historia: Las últimas cosas antes de las últimas. Buenos Aires: Las cuarenta.

Lukács, G. (2010). Teoría de la novela: Un ensayo histórico-filosófico sobre las formas de la gran literatura épica. Buenos Aires: Godot.

Machado, C., \& Vedda, M. (2010). Siegfried Kracauer: un pensador más allá de las fronteras. In. Buenos Aires: Gorla. 
Perivolaropoulou, N. (2004). Le travail de la mémoire: dans Theory of Film de Siegfried Kracauer. Protée, 32(1), pp. 39-48.

Rancière, J. (2001). La fable cinématographique. París: Seuil.

Schlüpmann, H. (1991). The Subject of Survival: On Kracauer's Theory of Film. New German Critique(54), pp. 111-126.

Traverso, E. (1998). Siegfried Kracauer: itinerario de un intelectual nómada. Valencia: Alfons el Magnànim.

Vedda, M. A. (2011). La irrealidad de la desesperación: estudios sobre Siegfried Kracauer y Walter Benjamin. Buenos Aires: Editorial Gorla.

Vedda, M. A. (2013). Calles sin recuerdo: la fenomenología de la gran ciudad en Siegfried Kracauer y Walter Benjamin. Impulso, 23, pp. 79-86.

Von Moltke, J. (2010). Ruin cinema. In J. H. a. A. Schönle (Ed.), Ruins of modernity (pp. 395-417). London: Duke University Press. 